\title{
An Efficient Lewis Acid Catalyzed Povarov Reaction for the One-Pot Stereocontrolled Synthesis of Polyfunctionalized Tetrahydroquinolines
}

\author{
Cristina Cimarelli*a \\ Samuele Bordia \\ Pamela Piermattei \\ Maura Pellei \\ Fabio Del Bello ${ }^{\mathrm{b}}$ \\ Enrico Marcantonia \\ a School of Science and Technology - Chemistry Division, \\ University of Camerino, Via S. Agostino 1, 62032 Camerino, \\ Italy \\ cristina.cimarelli@unicam.it \\ b School of Pharmacy - Medicinal Chemistry Unit, University \\ of Camerino, Via S. Agostino 1, 62032 Camerino, Italy
}

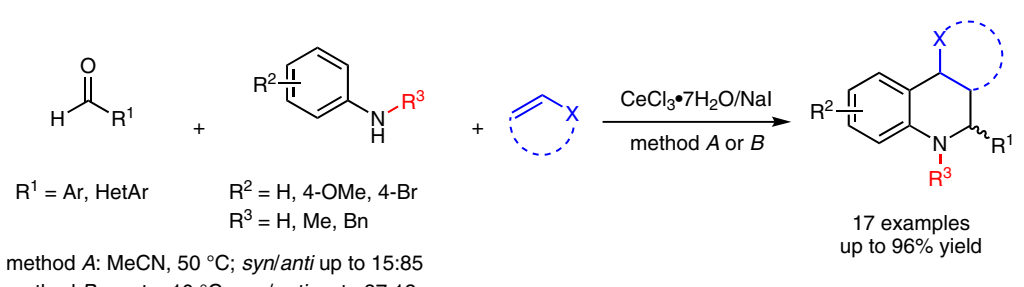

Received: 13.07.2017

Accepted after revision: 09.08.2017

Published online: 07.09.2017

DOI: 10.1055/s-0036-1589104; Art ID: ss-2017-t0457-op

Abstract An easy and efficient synthetic methodology for the one-pot stereocontrolled synthesis of tetrahydroquinolines through Lewis acid activated Povarov reaction is described. The protocol takes advantage of the very cheap, easy to handle, and environmentally friendly cerium trichloride as catalyst and allows to obtain either the anti- or the synisomer of the final tetrahydroquinoline with good selectivity, by performing the reaction in solvent or solventless conditions. The scope of the reaction is expanded to the one-pot synthesis of $\mathrm{N}$-alkyltetrahydroquinolines through a very efficient iminium-Povarov approach. A deeper insight on the reaction system was provided by the study on the side reactions occurring in the reaction conditions and on the nature of the stereoselectivity.

Key words tetrahydroquinoline derivatives, Povarov reaction, Lewis acid catalysis, cerium, solventless reactions

The Povarov reaction, ${ }^{1,2}$ - the aza-Diels-Alder reaction of electron-poor 2-azabutadienes with electron-rich dienophiles - is one of the more common pathways for the synthesis of fused-ring heterocyclic compounds, both in the two and three components version, depending on the preformation of the imine or the direct mixing of all the starting materials. Many catalysts have been used to activate the reagents: Brønsted ${ }^{3}$ and Lewis ${ }^{4}$ acids, also supported, ${ }^{5,6}$ and enzyme catalysis ${ }^{7}$ were investigated with different results.

Efforts are made to develop new methodologies, oriented towards more efficient and environment friendly Lewis acids, and to bypass the step of pre-formation of imines, compounds that are difficult to synthesize and unstable in many cases.

In the last years, the search for economic and environmentally benign synthetic methodologies has stimulated the use of nontoxic and inexpensive catalytic systems, and in this perspective Lanthanides ${ }^{8}$ have played an important role. Trivalent rare earth compounds salts, such as Ce(III) exhibit characteristic acid properties, and they activate Lewis base functionalities to promote useful organic transformations. For this reason numerous reactions and methodologies have been developed that involves cerium(III) as $\mathrm{CeCl}_{3}$, its more available source, as key component. ${ }^{9}$

Cerium trichloride has become interesting because of its high efficiency, low toxicity, and cost and for the ease of application also in non-anhydrous conditions. ${ }^{10}$ Furthermore, this environment friendly, cheap, highly efficient Lewis acid has just been widely applied as catalyst for the synthesis of heterocyclic compounds. ${ }^{11}$ Even if the $\mathrm{CeCl}_{3} \cdot 7 \mathrm{H}_{2} \mathrm{O}$ has been used as catalyst in multicomponent reactions $^{12}$ for generating new products in a single step and avoiding large amounts of solvents and expensive purification techniques, ${ }^{13}$ to the best of our knowledge there is no report on its use in the cyclization of acyclic precursors to fused-ring heterocycles. Often reactions catalyzed by $\mathrm{CeCl}_{3} \cdot 7 \mathrm{H}_{2} \mathrm{O}$ require a stoichiometric amount of this Lewis acid and long reaction times. A more reactive form of this catalyst is represented by the promoting system $\mathrm{CeCl}_{3} \cdot 7 \mathrm{H}_{2} \mathrm{O} / \mathrm{NaI}$ in $1: 1$ ratio, ${ }^{14}$ used in catalytic amount in a wide range of reactions. ${ }^{15}$

As part of our ongoing efforts on the synthesis of heterocycles, and considering that lanthanides have just been used in imino-Diels-Alder reactions ${ }^{16}$ and that a number of biologically active compounds with interesting properties have their structures based on the tetrahydroquinoline scaffold, ${ }^{17}$ we thought about exploring the application of the $\mathrm{CeCl}_{3} \cdot 7 \mathrm{H}_{2} \mathrm{O} / \mathrm{NaI}$ system as Lewis acid catalyst in the Povarov reaction, for the one-pot synthesis of a series of substituted pyranotetrahydroquinolines.

Indeed pyranequinoline skeleton is present in a series of natural products and biologically active compounds with interesting pharmaceutical activities namely anti-Alzheimer, ${ }^{18}$ antiallergic, ${ }^{19}$ anti-inflammatory, ${ }^{20}$ and some mole- 
cules with this structure find application in mammalian cell imaging. ${ }^{19}$ In addition, several heterocycles for industri-

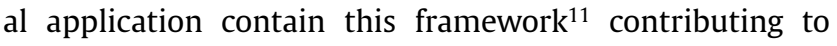
make the synthesis of these derivatives an important challenge.

The reaction was studied in solvent and under solventless conditions and the method has been extended also to other dienophiles and N-substituted anilines.

The pilot reaction was carried out in different conditions using aniline (1a), benzaldehyde (2a), and 3,4-dihydro- $2 \mathrm{H}$-pyran (3a, DHP), exploring $\mathrm{CeCl}_{3} \cdot 7 \mathrm{H}_{2} \mathrm{O} / \mathrm{NaI}$ as promoting system to find the best reaction conditions, as described in Table 1. Given that the required 2-azabutadienes are not stable in the presence of moisture, we chose to prepare them in situ. To avoid the formation of by-products from the reaction between aniline and dihydropyran, ${ }^{22} \mathbf{1 a}$ and $2 \mathbf{a}$ were stirred in the solvent, in the presence of magnesium sulfate, and after the quantitative formation of the corresponding imine, monitored by TLC and GC and by
NMR in some cases, DHP (3a) and the catalyst were added. The reaction was monitored by GC-MS and TLC until the starting reagents were consumed or a constant composition of the mixture was reached, and the final tetrahydroquinolines $\mathbf{4 a a}$ and $\mathbf{5 a}$ a were obtained as racemates in syn/antidiastereomer mixture. The results obtained are reported in Table 1.

In acetonitrile at room temperature, the reaction with an equimolecular amount of $\mathrm{CeCl}_{3} \cdot 7 \mathrm{H}_{2} \mathrm{O} / \mathrm{NaI}$, with respect to the substrates, gave $67 \%$ yield, while with a $30 \% \mathrm{~mol}$ amount of catalyst a very similar $70 \%$ yield was obtained in a slightly longer reaction time (Table 1 , entries 1,2 ). The reaction is anti-diastereoselective, with a syn/anti ratio of 28:72 in the first case and the ratio increased to 18:82 in the second. A further lowering to $10 \% \mathrm{~mol}$ of the catalyst system resulted again in a comparable yield, but the reaction time rose to 24 hours with a lower diastereoselectivity (entry 3 ). The reaction performed in toluene or 1,4-dioxane led to lower yields and with very long reaction times (en-

Table 1 Solvent, Catalyst, and Temperature Optimization of the Pilot Reaction

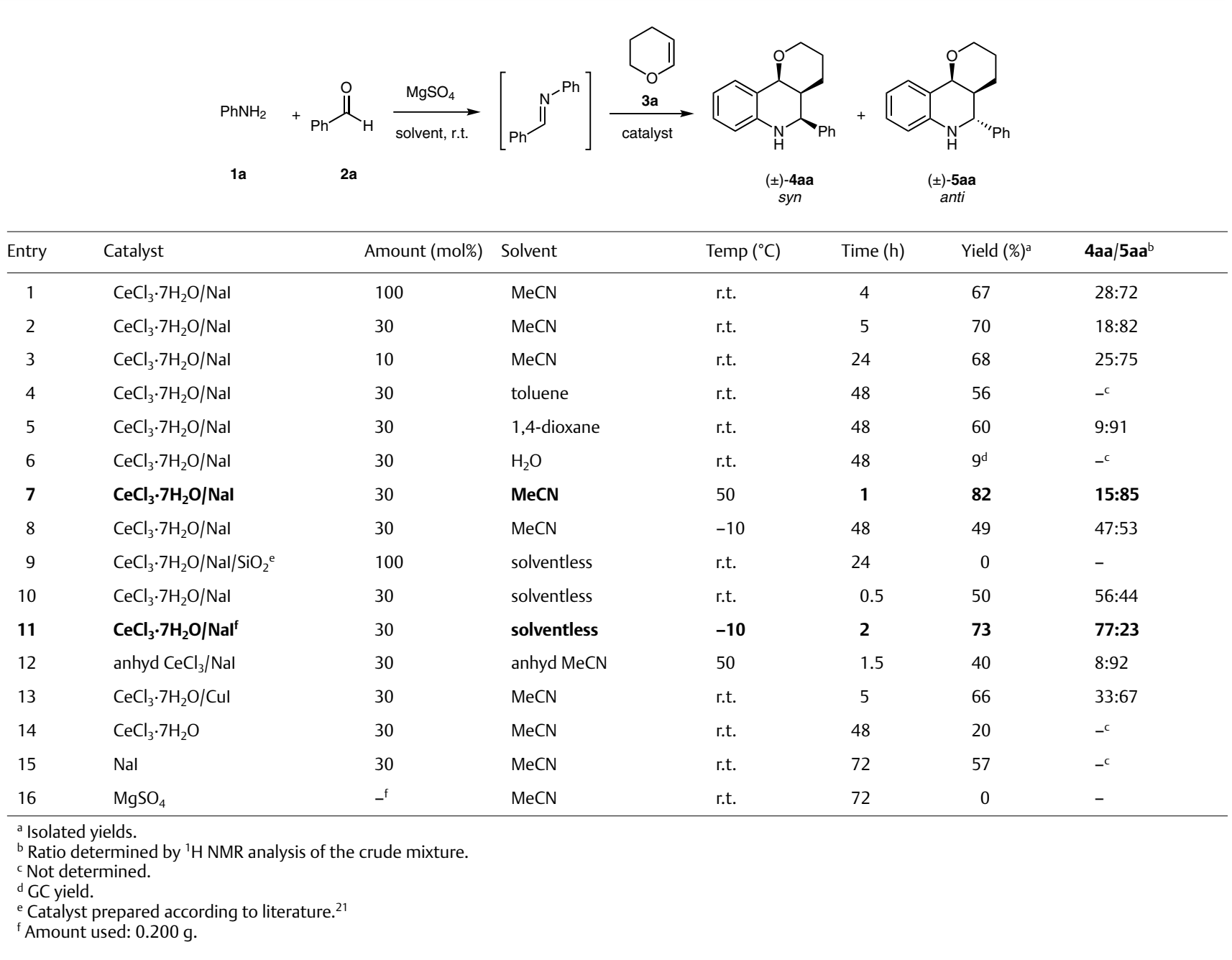


tries 4,5$)$. Really poor yields were obtained in water, affording to a synthetically useless result (entry 6); on the other hand anhydrous $\mathrm{CeCl}_{3} / \mathrm{NaI}$ in anhydrous acetonitrile at $50{ }^{\circ} \mathrm{C}$ led to an excellent syn/anti ratio of $8: 92$, but in only $40 \%$ yield (entry 12 ). Both yield and diastereoselectivity increased when the reaction was performed at $50{ }^{\circ} \mathrm{C}$ and the reaction time decreased to 1 hour (entry 7 ). Although the yield obtained using $\mathrm{Cul}$ as efficient iodide source instead of $\mathrm{NaI}^{23}$ was comparable, the corresponding diastereoselectivity was lower (entry 13). The reaction was attempted also under solventless conditions with interesting results (entries 9-11). The $\mathrm{SiO}_{2}$ supported $\mathrm{CeCl}_{3} \cdot 7 \mathrm{H}_{2} \mathrm{O} / \mathrm{NaI}$ system ${ }^{24}$ gave no reaction, but the solventless reaction without $\mathrm{SiO}_{2}$, performed by adding the dienophile and $30 \% \mathrm{~mol}$ of the catalytic mixture $\mathrm{CeCl}_{3} \cdot 7 \mathrm{H}_{2} \mathrm{O} / \mathrm{NaI}$ to the preformed imine, afforded $50 \%$ yield at room temperature with a slight preference for the syn-diastereomer. Lowering the temperature to $-10{ }^{\circ} \mathrm{C}$ allowed to obtain a $73 \%$ yield with an interesting inverted diastereoselectivity with respect to reaction performed in solvent (entries 7, 11). Further, although in our previous papers, $\mathrm{SiO}_{2}$ has been introduced as a support that facilitates the workup of the reaction mixture and to change the environment of the catalyst active site, ${ }^{25,26}$ under our present conditions the Povarov reaction did not take place in the presence of $\mathrm{SiO}_{2}$.

The components of the promoting system ${ }^{14}$ work in synergy, and we encountered no difficulty to perform our reaction under solventless conditions because one of the components is always liquid: the results obtained with $\mathrm{CeCl}_{3} \cdot 7 \mathrm{H}_{2} \mathrm{O}$ or NaI alone were really worse and required longer reaction times than that obtained with both components together (Table 1, entries 14, 15). Magnesium sulfate was not removed from the reaction system after the imine formation step, because it has no effect on the following reaction (entry16).

Generally the reactions performed in solvent show a strong preference for the anti-diastereomer together with slightly lower yields with respect to those under solventless conditions. This difference may depend on a different selectivity of the reaction itself and at the same time on a different stability of the two diastereomers in the reaction mixture.

Experiments were made to ascertain if the selectivity depends on a kinetic or thermodynamic control of the reaction system in the different conditions. Generally high concentration and low temperatures favor the kinetic control of a reaction, while high dilution condition and higher temperature allow the thermodynamic control.

We performed the reaction in different conditions of solvent and temperature, monitoring the diastereomer ratio at different reaction times and stopping the reaction at 4 hours, unless differently stated. We observed that at $-10{ }^{\circ} \mathrm{C}$ only 5 equivalents of solvent are enough to decrease the syn selectivity shown in the reaction under solventless conditions (Table 1 , entry 11 ) from $77: 23$ to $54: 46$. The trend is confirmed by data of the reactions performed in the same conditions of time and temperature, in 5 and $10 \mathrm{~mL}$ of solvent, that showed an increasing anti selectivity of 35:65 and 17:83, respectively. After 4 hours, all the reaction mixtures were left to reach room temperature and stirred overnight, and all resulted enriched in the anti-diastereomer. These observations confirm that under kinetically controlled conditions at high concentrations and at low temperatures, the syn product is favored, and low concentration, long reaction times and high dilutions favor the formation of the anti-diastereomer.

The issue of the different stability of the two diastereomers in the reaction mixture was addressed with a further experiment. A mixture of the two diastereomers $($ syn/anti $=$ 41:59) was dissolved in $\mathrm{MeCN}$, the catalyst was added and left stirring overnight at room temperature. After this period, the diastereomers were isolated as a mixture, and the yield and the d.r. were determined. The syn/anti ratio passed to 32:68, showing that the mixture was enriched in the anti-diastereomer. At the same time, only the $82 \%$ of the initial amount of the mixture was recovered, that in more detail revealed a $5 \%$ loss of the anti-product and a $37 \%$ loss of the syn (Scheme 1).

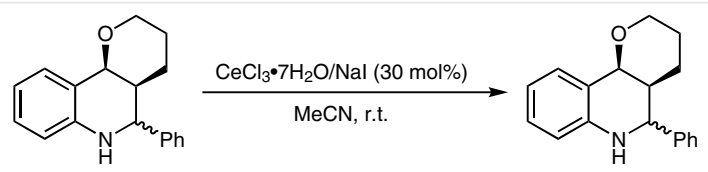

$$
\begin{array}{cr}
( \pm)-4 a a,( \pm)-5 a a & ( \pm)-4 a a,( \pm)-5 a a \\
\text { d.r. } 41: 59 & 82 \% \text {; d.r. 32:68 }
\end{array}
$$

Scheme 1 Stability of the syn/anti-diastereomers in the reaction mixture

These results confirm that the selectivity of this reaction depends both on kinetic and thermodynamic control under the different reaction conditions and on a different stability of the two diastereomers in the reaction mixture. At the same time they parallel the results reported by Shen's group on the samarium diiodide catalyzed Povarov reaction for the synthesis of pyranoquinolines. ${ }^{4 c}$

The generality of the reaction was explored with a series of anilines $\mathbf{1 a}-\mathbf{c}$ and aromatic aldehydes $\mathbf{2 a - \mathbf { g }}$ that were tested using both solvent and solventless optimized methods, as depicted in Scheme 2 (method A or B), obtaining in most cases good to excellent yields of the desired tetrahydroquinolines 4 and 5. Preliminary data obtained using aliphatic aldehydes gave poor results; further experiments are in progress in our laboratory. The reaction has a good functional group tolerance, performing better with electronwithdrawing groups on the aldehyde, while it is sluggish in the case of very electron-rich aldehydes (i.e., 3,4,5-trimethoxybenzaldehyde) or very electron-poor anilines (i.e., 4nitroaniline). GC-MS analysis of the reaction mixture of these aldehydes revealed only traces of the corresponding tetrahydroquinolines $\mathbf{4}$ and $\mathbf{5}$ even after 24 hours. This ef- 


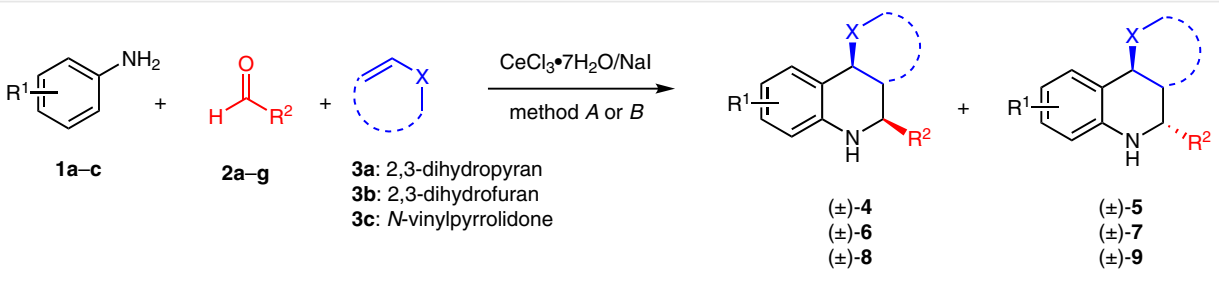

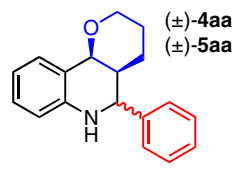

A: $1 \mathrm{~h}, 82 \%(15: 85)^{\mathrm{b}}$ B: 2 h, $73 \%(77: 23)$

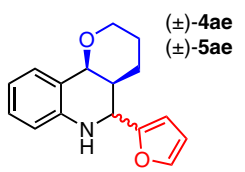

A: $2 \mathrm{~h}, 58 \%(19: 81)$ B: $8 \mathrm{~h}, 46 \%(76: 24)$
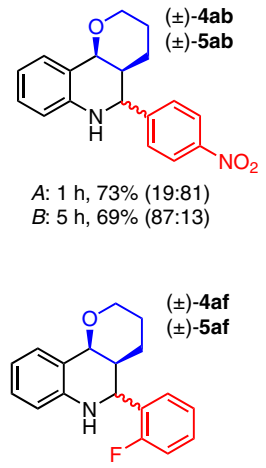

A: $3 \mathrm{~h}, 74 \%(22: 78)$ B: $7 \mathrm{~h}, 69 \%(81: 19)$

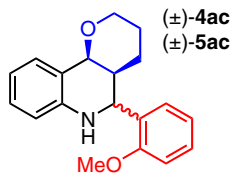

A: 5 h, $86 \%(15: 85)$ B: 12 h, $71 \%(76: 24)$

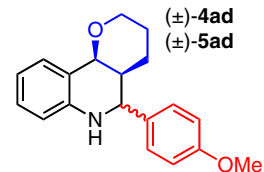

A: $6 \mathrm{~h}, 88 \%(25: 75)$ B: $18 \mathrm{~h}, 60 \%(60: 40)$

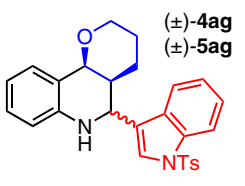

A: 4 h, $86 \%$ (32:68) A: $4 \mathrm{~h}, 8 \mathrm{c}$
$B:-\mathrm{c}$

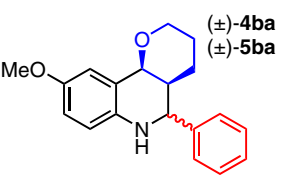

A: $6 \mathrm{~h}, 60 \%(22: 78)$ B: $18 \mathrm{~h}, 60 \%(81: 19)$

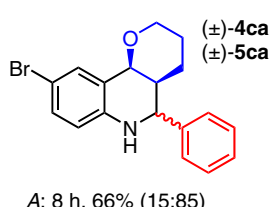

A: 8 h, $66 \%(15: 85)$

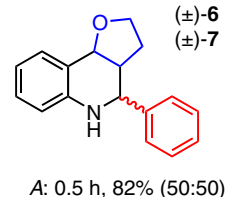

(土)-6

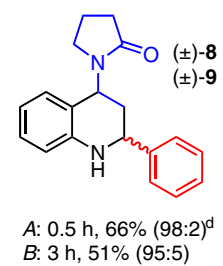

Scheme 2 Synthesis of tetrahydroquinolines and $\mathrm{N}$-alkyltetrahydroquinolines by $\mathrm{CeCl}_{3} \cdot 7 \mathrm{H}_{2} \mathrm{O} / \mathrm{Nal}$ catalyzed Povarov reaction. ${ }^{\text {a }}$ Reagents and conditions: Method $\mathrm{A}$ : aniline $\mathbf{1 a}-\mathbf{c}(1 \mathrm{mmol})$, aldehyde $\mathbf{2 a}-\mathbf{g}(1 \mathrm{mmol})$, dienophile $\mathbf{3 a}-\mathbf{c}(1.2 \mathrm{mmol}), \mathrm{CeCl}_{3} \cdot 7 \mathrm{H}_{2} \mathrm{O}(0.3 \mathrm{mmol}), \mathrm{Nal}(0.3 \mathrm{mmol})$, and $\mathbf{M g S O}{ }_{4}(200$ $\mathrm{mg}$ ), stirred together in MeCN (5 mL) at $50{ }^{\circ} \mathrm{C}$. Method B: pure isolated imine synthesized from aniline $\mathbf{1}$ and aldehyde $\mathbf{2}$ (1 mmol), dienophile $\mathbf{3}$ (1.5 $\mathrm{mmol}), \mathrm{CeCl}_{3} \cdot 7 \mathrm{H}_{2} \mathrm{O}(0.3 \mathrm{mmol})$, and $\mathrm{Nal}(0.3 \mathrm{mmol})$ stirred at $-10{ }^{\circ} \mathrm{C}$ without solvent. ${ }^{\mathrm{b}}$ Syn/anti ratio determined by ${ }^{1} \mathrm{H} \mathrm{NMR}$ spectroscopy of the crude. c Not determined due to the stickiness of the mixture. ${ }^{d}$ Reaction performed at r.t.

fect is enhanced in the solvent-free reaction, that seems to proceed very slowly or not at all in the examples cited above.

The scope of the reaction was extended also to dienophiles other than DMP (3a). Beyond the classical candidate 2,3-dihydrofuran (3b), $N$-vinylpyrrolidone (3c) was also used under conditions according to both methods $\mathrm{A}$ and $\mathrm{B}$. 2,3-Dihydrofuran derivatives syn-6 and anti-7 were obtained in short reaction times, probably because of the higher energy of the more strained double bond in the fivemembered ring, but unfortunately the reaction was unselective in both conditions, because of the reduced steric hindrance of the furan ring with respect to pyran. Different results were obtained with $N$-vinylpyrrolidone (3c), that afforded products syn-8 and anti-9 with acceptable yields and with a strong preference for the syn-product.

The good results obtained with the classical Povarov reaction prompted us to test iminium ions as heterodienes, similar to the benzotriazole approach reported by Katritzky's group, ${ }^{27}$ with the result of overcoming the two main drawbacks of this methodology: the synthesis of the starting benzotriazole derivative and a little atom economy. Further applications of our approach are under study.

$\mathrm{N}$-Methylaniline (1d) or $\mathrm{N}$-benzylaniline (1e), formaldehyde (2h) or ethyl glyoxylate (2i) and dienophiles $\mathbf{3 a - c}$ were mixed in acetonitrile and stirred together at room temperature with the catalytic system, according to method A. To our delight, reactions were complete in 0.5-5 hours, giving yields up to $96 \%$ of the desired $N$-alkyltetrahydroquinolines 10a-d, as depicted in Scheme 3.

This approach was applied to the synthesis of julolidine-type compound 11. A probable reaction pathway is described in Scheme 4: the imine formed by the reaction of aniline with formaldehyde reacts according to Povarov mechanism with dihydrofuran. The amino group contained into the intermediate dihydroquinoline can form an iminium ion by reaction with a second molecule of formaldehyde and then a second Povarov reaction takes place, yielding product 11. Also another julolidine-type synthesis through 


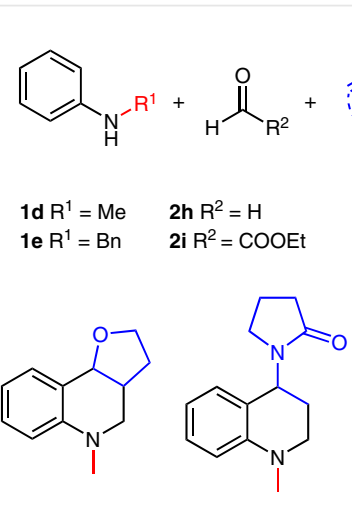

$10 a$
$96 \%, 0.5 \mathrm{~h}$

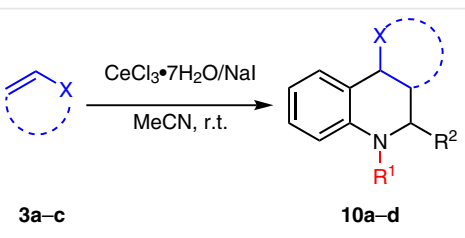<smiles>c1ccc(CN2CC3CCCOC3c3ccccc32)cc1</smiles>

$10 c$
$60 \%, 2 h$

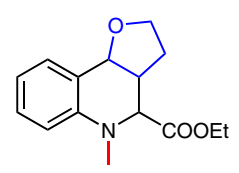

$10 \mathrm{~d}^{\mathrm{a}}$

$36 \%, 1 \mathrm{~h}$

Scheme 3 Synthesis of $\mathrm{N}$-alkyltetrahydroquinolines by $\mathrm{CeCl}_{3} \cdot 7 \mathrm{H}_{2} \mathrm{O} / \mathrm{Nal}$ catalyzed Povarov reaction. Reagents and conditions: $1 \mathbf{d}-\mathbf{e}(1 \mathrm{mmol})$, $\mathbf{2 h}-\mathbf{i}(1.2 \mathrm{mmol}), \mathbf{3 a}-\mathbf{c}(1.2 \mathrm{mmol}), \mathrm{CeCl}_{3} \cdot 7 \mathrm{H}_{2} \mathrm{O}$, Nal $(0.3 \mathrm{mmol})$, and $\mathrm{MgSO}_{4}(200 \mathrm{mg})$ were stirred together in $\mathrm{MeCN}(5 \mathrm{~mL})$ at r.t. ${ }^{\text {a Product }}$ 10d was obtained as a 53:47 syn/anti mixture.

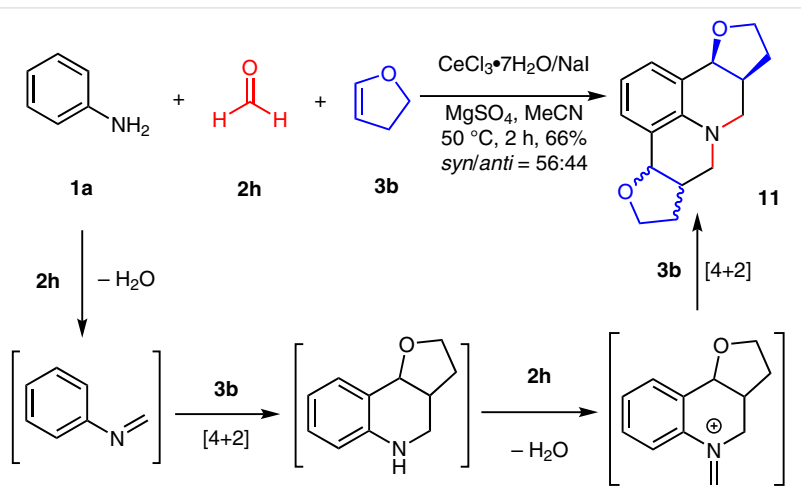

Scheme 4 One-pot synthesis of the julolidine 11. Reagents and conditions: $\mathbf{1 a}(1 \mathrm{mmol}), \mathbf{2} \mathbf{h}(2.2 \mathrm{mmol}), \mathbf{3 b}(2.4 \mathrm{mmol}), \mathrm{CeCl}_{3} \cdot 7 \mathrm{H}_{2} \mathrm{O}$, Nal $(0.3$ $\mathrm{mmol})$, and $\mathrm{MgSO}_{4}(200 \mathrm{mg})$ were stirred together in $\mathrm{MeCN}(5 \mathrm{~mL})$ at $50{ }^{\circ} \mathrm{C}$ for $2 \mathrm{~h}$.

Povarov reaction is known in literature ${ }^{28}$ that takes place in the absence of any catalyst, but is performed in the more toxic and expensive trifluoroethanol.

Despite the good outcomes of these reactions, yields rarely rose above $90 \%$, because of some side reactions that generated byproducts, making the purification more difficult as well. In these reactions, especially using $\mathbf{3 a}$ as dienophile, we observed products 12 and 13 (Figure 1 ) in significant amounts during the GC-MS analysis of the reaction crude.

By-product 12 is due to opening of the tetrahydropyran ring by the starting aniline that leads to an imine by-product, which reacts as a diene with another dihydropyran molecule according to the Povarov mechanism and affords tetrahydroquinoline $14 .^{29}$ This hypothesis was confirmed

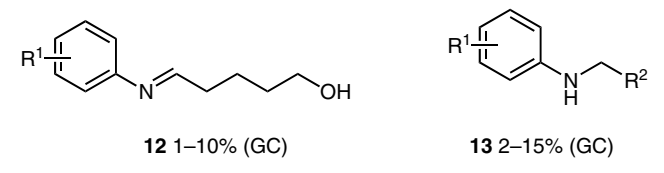

Figure 1 Recurrent by-products observed in GC-MS analysis of the crude

by mixing 1a together with a two-fold excess of 3a under the reaction conditions, and observing that product 14 was formed in $45 \%$ of isolated yield, as described in Scheme 5.

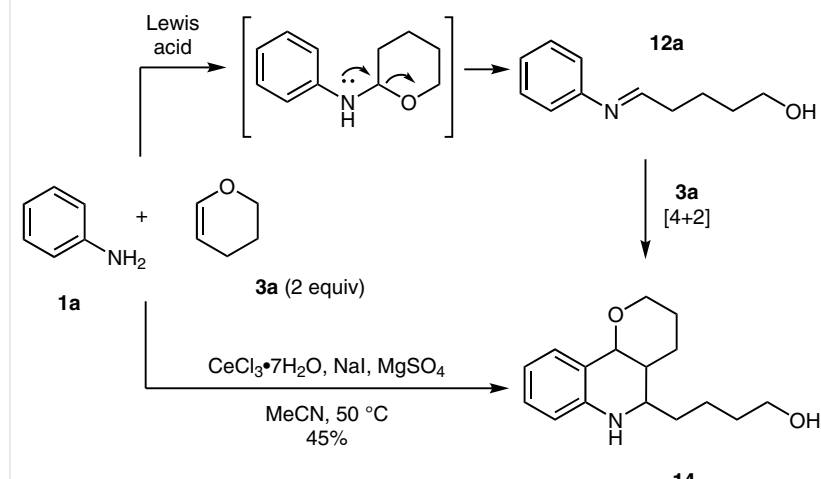

14

Scheme 5 Formation of by-product $\mathbf{1 2 a}$ and further reaction with $\mathbf{3 a}$

On the other hand, by-products like $\mathbf{1 3}$ were already reported in the Povarov reaction. The coordination of Cerium with the oxygen atom in tetrahydroquinolines $\mathbf{4}$ and $\mathbf{5}$ favors the ether ring opening, ${ }^{30}$ then the iminodiene acts as hydrogen acceptor in the oxidation to quinoline by an hydrogen transfer mechanism. ${ }^{31}$

Furthermore tetrahydropyranylation of the free hydroxyl groups could occur, because of the known ability of $\mathrm{CeCl}_{3} \cdot 7 \mathrm{H}_{2} \mathrm{O} / \mathrm{NaI}$ to catalyze this kind of protection of alcohols. ${ }^{32}$ The crude mixture of the preparation of compounds 4ae and 5ae was submitted to ESI-MS analysis and the presence of all the hypothesized by-products, which cannot be identified by GC-MS analysis, was clearly shown (see Supporting Information).

In conclusion, a one-pot methodology for the stereoselective synthesis of tetrahydroquinolines, based on the Povarov reaction catalyzed by the scarcely toxic, easily handled and efficient Lewis acid $\mathrm{CeCl}_{3} \cdot 7 \mathrm{H}_{2} \mathrm{O}$, in combination with NaI, was developed. A series of tetrahydroquinolines was obtained, in good yields, from aromatic amines, aromatic aldehydes, and DHP. The stereoselectivity of the reaction can be driven toward the anti- or the syn-diastereomer by choosing solvent or solventless reaction conditions. The analysis of the reaction mixture allowed the identification of the different reaction pathways that may take place in the system and consequently the main by-products, responsible for the sometimes troublesome purification of the products. The ability of iminium ions to act as Povarov 
activated dienes in this protocol was also explored, leading to up to $96 \%$ yield of the desired $\mathrm{N}$-alkyltetrahydroquinoline products. In addition to demonstrating the efficiency of our $\mathrm{CeCl}_{3} \cdot 7 \mathrm{H}_{2} \mathrm{O} / \mathrm{NaI}$ catalytic system in the formation of new carbon-carbon bonds by a multicomponent method, our present methodology has evidenced its further application in organic synthesis in the cyclization to fused-ring heterocycles. Further studies in order to explore the application of our protocol in heterocyclic systems with more different heteroatoms are currently underway.

All reagents and solvents were purchased from commercial suppliers and used without further purification, unless mentioned otherwise. Formaldehyde was used as a $37 \%$ wt. solution in $\mathrm{H}_{2} \mathrm{O}$. All reactions were monitored by TLC using EMD/Merck silica gel 60 precoated plates $(0.25 \mathrm{~mm})$, and the compounds were visualized either by using UV light (254 nm), and/or $\mathrm{I}_{2}$ vapors, vanillin, or $\mathrm{KMnO}_{4}$ stains as developing agents. Purification of the reaction products was carried out by column flash chromatography using silica gel (0.040-0.063 mesh). ${ }^{1} \mathrm{H},{ }^{13} \mathrm{C}$, and ${ }^{19} \mathrm{~F}$ NMR spectra were recorded on a Varian Mercury 400 (400 MHz, $100 \mathrm{MHz}$, or $377 \mathrm{MHz}$, respectively). Chemical shifts are given in $\mathrm{ppm}$ with reference to residual $\mathrm{H}$ in deuterated solvents as the internal standard. Coupling constants $J$ are reported in hertz $(\mathrm{Hz})$. Diastereomeric ratio was determined by integration of ${ }^{1} \mathrm{H}$ NMR signals of $\mathrm{H}-1$ and $\mathrm{H}-6$. Mass spectra were obtained using a gas chromatograph Agilent 6850 equipped with a HP5MS column $(0.25 \mathrm{~mm}$ diameter) and a mass-selective detector Agilent 5973N, or using a LCMS Hewlett Packard series 1100 MSD. Microanalyses were performed with an EA1108 CHNS-D Fisons Instrument. Melting points were determined in open capillary tubes on a Büchi 535 melting point apparatus and are uncorrected.

The analytical and spectral data of known products 4aa, 5aa; 4ab, 5ab; 4ac, 5ac; 4ad, 5ad; 4 ba, 5ba, $4 \mathrm{ca}, 5 \mathrm{ca}$; and 6-8 are provided in the Supporting Information.

\section{Tetrahydroquinolines 4 and 5}

\section{Method A}

In a round-bottomed flask, $N$-arylamine $\mathbf{1 a}-\mathbf{c}(1 \mathrm{mmol})$ and aldehyde 2a-g (1 mmol) were stirred together in $\mathrm{MeCN}(5 \mathrm{~mL})$ in the presence of anhyd $\mathrm{MgSO}_{4}(200 \mathrm{mg}$ ). The mixture was stirred until imine was completely formed (heating when required). Then, $\mathrm{CeCl}_{3} \cdot 7 \mathrm{H}_{2} \mathrm{O}(112$ $\mathrm{mg}, 0.3 \mathrm{mmol}$ ) and $\mathrm{NaI}(45 \mathrm{mg}, 0.3 \mathrm{mmol}$ ) were added, followed by the chosen dienophile $\mathbf{3 a}-\mathbf{c}(1.2 \mathrm{mmol})$ and the mixture was stirred at $50{ }^{\circ} \mathrm{C}$ until consumption of starting materials (TLC, hexane/EtOAc, vanillin stain). The mixture was diluted with $\mathrm{CH}_{2} \mathrm{Cl}_{2}(10 \mathrm{~mL})$ and washed with aq $0.5 \mathrm{M} \mathrm{HCl}(10 \mathrm{~mL})$. The aqueous layer was extracted with $\mathrm{CH}_{2} \mathrm{Cl}_{2}$, then treated with sat. aq $\mathrm{NaHCO}_{3}$ until basic pH was reached, and extracted again with $\mathrm{CH}_{2} \mathrm{Cl}_{2}$. The organic layers were combined, washed with brine, and dried (anhyd $\mathrm{Na}_{2} \mathrm{SO}_{4}$ ). The crude was purified by flash chromatography over silica gel (eluent hexane/EtOAc) to afford the pure desired tetrahydroquinoline product.

\section{Method B}

In a closed vial, pure isolated $\mathrm{N}$-arylimine $(1 \mathrm{mmol}$, prepared from 1a-c and 2a-g), dienophile $3 a-c(1.5 \mathrm{mmol}), \mathrm{CeCl}_{3} \cdot 7 \mathrm{H}_{2} \mathrm{O}(112 \mathrm{mg}, 0.3$ $\mathrm{mmol}$ ), and $\mathrm{NaI}\left(45 \mathrm{mg}, 0.3 \mathrm{mmol}\right.$ ) were stirred together at $-10{ }^{\circ} \mathrm{C}$ in an ice-salt bath until consumption of the starting imine. Workup and purification follow the procedure reported in Method A.

\section{( \pm )-(4aS,5S,10bS)-5-(Furan-2-yl)-3,4,4a,5,6,10b-hexahydro-2H- pyrano[3,2-c]quinoline (4ae)}

Prepared from aniline (1a), 2-furancarbaldehyde (2e), and 2,3-dihydropyran (3a) according to the general procedure; yield: $114 \mathrm{mg}$ (47\%); white solid; $\mathrm{mp} 156-158{ }^{\circ} \mathrm{C}$.

FT-IR (neat): 3322, 2938, 1602, 1483, 1063, 752, $723 \mathrm{~cm}^{-1}$.

${ }^{1} \mathrm{H} \mathrm{NMR}\left(\mathrm{CDCl}_{3}, 400 \mathrm{MHz}\right): \delta=7.43(\mathrm{~d}, J=7.5 \mathrm{~Hz}, 1 \mathrm{H}), 7.42-7.41(\mathrm{~m}, 1$ H), 7.12-7.08 (m, $1 \mathrm{H}), 6.82(\mathrm{t}, J=7.5 \mathrm{~Hz}, 1 \mathrm{H}), 6.61(\mathrm{~d}, J=8.0 \mathrm{~Hz}, 1 \mathrm{H})$, 6.40-6.39 (m, $1 \mathrm{H}), 6.31(\mathrm{dd}, J=3.3,0.8 \mathrm{~Hz}, 1 \mathrm{H}), 5.24(\mathrm{~d}, J=5.6 \mathrm{~Hz}, 1$ H), $4.72(\mathrm{~d}, J=2.6 \mathrm{~Hz}, 1 \mathrm{H}), 4.00(\mathrm{br} \mathrm{s}, 1 \mathrm{H}), 3.63-3.59(\mathrm{~m}, 1 \mathrm{H}), 3.43$ (td, $J=11.8,1.9 \mathrm{~Hz}, 1 \mathrm{H}), 2.42-2.36(\mathrm{~m}, 1 \mathrm{H}), 1.70-1.46(\mathrm{~m}, 4 \mathrm{H})$.

${ }^{13} \mathrm{C}$ NMR $\left(\mathrm{CDCl}_{3}, 100 \mathrm{MHz}\right): \delta=154.3,144.6,141.8,128.3,127.9$, 120.3, 118.8, 114.8, 110.4, 106.3, 72.0, 60.9, 54.0, 36.5, 25.5, 19.0.

GC-MS (EI, $70 \mathrm{eV}): m / z=255$ [M+], 196 (100\%), 184, 168, 167, 130.

Anal. Calcd for $\mathrm{C}_{16} \mathrm{H}_{17} \mathrm{NO}_{2}$ (255.317): C, 75.27; $\mathrm{H}, 6.71 ; \mathrm{N}, 5.49$. Found: C, 75.25; H, 6.64; N, 5.58.

\section{( \pm )-(4aS,5R,10bS)-5-(Furan-2-yl)-3,4,4a,5,6,10b-hexahydro-2H- pyrano[3,2-c]quinoline (5ae)}

Prepared from aniline (1a), 2-furancarbaldehyde (2e), and 2,3 dihydropyran (3a) according to the general procedure; yield: $45 \mathrm{mg}$ (18\%); white solid; $\mathrm{mp} 126-128^{\circ} \mathrm{C}$.

FT-IR (neat): 3317, 2925, 2856, 1626, 1265, 1124, 1073, 1026, 749 $\mathrm{cm}^{-1}$.

${ }^{1} \mathrm{H} \mathrm{NMR}\left(\mathrm{CDCl}_{3}, 400 \mathrm{MHz}\right): \delta=7.42-7.41(\mathrm{~m}, 1 \mathrm{H}), 7.22(\mathrm{dd}, J=7.6,1.5$ $\mathrm{Hz}, 1 \mathrm{H}), 7.11-7.07(\mathrm{~m}, 1 \mathrm{H}), 6.72(\mathrm{t}, J=7.4 \mathrm{~Hz}, 1 \mathrm{H}), 6.56(\mathrm{~d}, J=8.1 \mathrm{~Hz}$, $1 \mathrm{H}), 6.37-6.36(\mathrm{~m}, 1 \mathrm{H}), 6.33(\mathrm{~d}, J=3.2 \mathrm{~Hz}, 1 \mathrm{H}), 4.83(\mathrm{~d}, J=10.5 \mathrm{~Hz}, 1$ $\mathrm{H}), 4.42(\mathrm{~d}, J=2.9 \mathrm{~Hz}, 1 \mathrm{H}), 4.07-4.02(\mathrm{~m}, 2 \mathrm{H}), 3.71(\mathrm{td}, J=11.2,2.5$ $\mathrm{Hz}, 1 \mathrm{H}), 2.30-2.25(\mathrm{~m}, 1 \mathrm{H}), 1.86-1.71(\mathrm{~m}, 2 \mathrm{H}), 1.58-1.54(\mathrm{~m}, 1 \mathrm{H})$, $1.43-1.37(\mathrm{~m}, 1 \mathrm{H})$.

${ }^{13} \mathrm{C}$ NMR $\left(\mathrm{CDCl}_{3}, 100 \mathrm{MHz}\right): \delta=155.2,144.1,142.5,130.9,129.5$, 121.0, 118.2, 114.8, 110.4, 107.8, 74.3, 68.4, 49.2, 37.3, 24.6, 22.3.

GC-MS (EI, $70 \mathrm{eV}): m / z=255\left[\mathrm{M}^{+}\right], 196(100 \%), 184,168,167,130$.

Anal. Calcd for $\mathrm{C}_{16} \mathrm{H}_{17} \mathrm{NO}_{2}$ (255.317): C, 75.27; $\mathrm{H}, 6.71 ; \mathrm{N}, 5.49$. Found: C, 75.32; H, 6.60; N, 5.62 .

\section{( \pm )-(4aS,5S,10bS)-5-(2-Fluorophenyl)-3,4,4a,5,6,10b-hexahydro- 2H-pyrano[3,2-c]quinoline (4af)}

Prepared from aniline (1a), 2-fluorobenzaldehyde (2f), and 2,3 dihydropyran (3a) according to the general procedure; yield: $157 \mathrm{mg}$ (56\%); white solid; $\mathrm{mp} 159-164{ }^{\circ} \mathrm{C}$.

FT-IR (neat): 3301, 2942, 1492, 1226, 1071, $746 \mathrm{~cm}^{-1}$.

${ }^{1} \mathrm{H} \mathrm{NMR}\left(\mathrm{CDCl}_{3}, 400 \mathrm{MHz}\right): \delta=7.65-7.58(\mathrm{~m}, 1 \mathrm{H}), 7.47-7.42(\mathrm{~m}, 1 \mathrm{H})$, 7.34-7.25 (m, $1 \mathrm{H}), 7.17$ (t, J = 7.5 Hz, $1 \mathrm{H}), 7.13-7.04$ (m, $2 \mathrm{H}), 6.85-$ $6.77(\mathrm{~m}, 1 \mathrm{H}), 6.63(\mathrm{~d}, J=8.0 \mathrm{~Hz}, 1 \mathrm{H}), 5.33(\mathrm{~d}, J=5.6 \mathrm{~Hz}, 1 \mathrm{H}), 5.03(\mathrm{~d}$, $J=2.3 \mathrm{~Hz}, 1 \mathrm{H}$ ), 3.76 (br s, $1 \mathrm{H}), 3.64-3.57$ (m, $1 \mathrm{H}), 3.49-3.36$ (m, $1 \mathrm{H}$ ), 2.34-2.27 (m, $1 \mathrm{H}), 1.66-1.39$ ( $\mathrm{m}, 3 \mathrm{H}), 1.36-1.18(\mathrm{~m}, 1 \mathrm{H})$.

${ }^{13} \mathrm{C} \mathrm{NMR}\left(\mathrm{CDCl}_{3}, 100 \mathrm{MHz}\right): \delta=160.2\left(\mathrm{~d}, J_{\mathrm{C}, \mathrm{F}}=246.7 \mathrm{~Hz}\right), 145.3,129.0$ $\left(\mathrm{d}, J_{C, \mathrm{~F}}=8.4 \mathrm{~Hz}\right), 128.4\left(\mathrm{~d}, J_{\mathrm{C}, \mathrm{F}}=11.9 \mathrm{~Hz}\right), 128.3,128.2\left(\mathrm{~d}, J_{\mathrm{C}, \mathrm{F}}=4.2 \mathrm{~Hz}\right)$, 127.9, $124.0\left(\mathrm{~d}, J_{\mathrm{C}, \mathrm{F}}=3.5 \mathrm{~Hz}\right), 120.3,118.8,115.7\left(\mathrm{~d}, J_{\mathrm{C}, \mathrm{F}}=21.6 \mathrm{~Hz}\right)$, $114.9,72.6,60.8,52.4\left(\mathrm{~d}, J_{\mathrm{C}, \mathrm{F}}=3.0 \mathrm{~Hz}\right), 36.6,25.6,18.6$.

${ }^{19} \mathrm{~F} \mathrm{NMR}\left(\mathrm{CDCl}_{3,}, 377 \mathrm{MHz}\right): \delta=-119.5$.

GC-MS (EI, $70 \mathrm{eV}$ ): $m / z=283$ [M+1, 252, 224 (100\%), 212, 130, 109, 77. Anal. Calcd for $\mathrm{C}_{18} \mathrm{H}_{18} \mathrm{FNO}$ (283.346): C, 76.30; H, 6.40; N, 4.94. Found: C, 76.34; H, 6.47; N, 4.87 . 


\section{( \pm )-(4aS,5R,10bS)-5-(2-Fluorophenyl)-3,4,4a,5,6,10b-hexahydro-} 2H-pyrano[3,2-c]quinoline (5af)

Prepared from aniline (1a), 2-fluorobenzaldehyde (2f), and 2,3-dihydropyran (3a) according to the general procedure; yield: $155 \mathrm{mg}$ (56\%); white foamy solid; $\mathrm{mp} 47-50^{\circ} \mathrm{C}$.

FT-IR (neat): 3354, 2938, 2852, 1610, 1483, 1079, $748 \mathrm{~cm}^{-1}$.

${ }^{1} \mathrm{H} \mathrm{NMR}\left(\mathrm{CDCl}_{3}, 400 \mathrm{MHz}\right): \delta=7.54(\mathrm{td}, J=7.5,1.6 \mathrm{~Hz}, 1 \mathrm{H}), 7.34-7.24$ (m, $2 \mathrm{H}$ ), 7.18 (td, $J=7.5,1.1 \mathrm{~Hz}, 1 \mathrm{H}), 7.14-7.04(\mathrm{~m}, 2 \mathrm{H}), 6.74$ (td, $J=$ 7.4, $1.1 \mathrm{~Hz}, 1 \mathrm{H}), 6.56(\mathrm{~d}, J=8.1 \mathrm{~Hz}, 1 \mathrm{H}), 5.13(\mathrm{~d}, J=10.4 \mathrm{~Hz}, 1 \mathrm{H}), 4.43$ (d, $J=2.9 \mathrm{~Hz}, 1 \mathrm{H}), 4.10-4.04(\mathrm{~m}, 1 \mathrm{H}), 4.09(\mathrm{br} \mathrm{s}, 1 \mathrm{H}), 3.72(\mathrm{td}, J=$ 11.3, $2.6 \mathrm{~Hz}, 1 \mathrm{H}$ ), 2.21-2.11 (m, $1 \mathrm{H}$ ), 1.92 (qt, $J=12.5,4.2 \mathrm{~Hz}, 1 \mathrm{H}$ ), $1.72(\mathrm{tt}, J=13.2,4.7 \mathrm{~Hz}, 1 \mathrm{H}), 1.56-1.46(\mathrm{~m}, 1 \mathrm{H}), 1.44-1.35(\mathrm{~m}, 1 \mathrm{H})$.

${ }^{13} \mathrm{C} \mathrm{NMR}\left(\mathrm{CDCl}_{3}, 100 \mathrm{MHz}\right): \delta=161.3\left(\mathrm{~d}, J_{\mathrm{C}, \mathrm{F}}=246.8 \mathrm{~Hz}\right), 144.7,130.9$, $129.5,129.4\left(\mathrm{~d}, J_{\mathrm{C}, \mathrm{F}}=8.4 \mathrm{~Hz}\right), 129.2\left(\mathrm{~d}, J_{\mathrm{C}, \mathrm{F}}=4.0 \mathrm{~Hz}\right), 124.8\left(\mathrm{~d}, J_{\mathrm{C}, \mathrm{F}}=3.4\right.$ $\mathrm{Hz}), 120.8,118.0,115.7$ (d, $\left.J_{\mathrm{CF}}=22.5 \mathrm{~Hz}\right), 114.5,74.3,68.4,47.9,38.6$, 24.6, 22.5 .

${ }^{19} \mathrm{~F}$ NMR $\left(\mathrm{CDCl}_{3}, 377 \mathrm{MHz}\right): \delta=-118.6$.

GC-MS (EI, $70 \mathrm{eV}): m / z=283\left[\mathrm{M}^{+}\right], 252,224$ (100\%), 212, 130, 109, 77. Anal. Calcd for $\mathrm{C}_{18} \mathrm{H}_{18} \mathrm{FNO}$ (283.346): C, 76.30; H, 6.40; N, 4.94. Found: C, 76.28; H, 6.45; N, 4.98 .

\section{( \pm )-(4aS,5S,10bS)-5-(1-Tosyl-1H-indol-3-yl)-3,4,4a,5,6,10b-hexahy-} dro-2H-pyrano[3,2-c]quinoline (4ag)

Prepared from aniline (1a), $N$-tosylindole-3-carboxaldehyde (2g), and 2,3-dihydropyran (3a) according to the general procedure; yield: 257 mg (58\%); white solid; $\mathrm{mp} 121{ }^{\circ} \mathrm{C}$ (dec.).

FT-IR (neat): 3380, 2931, 1605, 1368, 1168, 743, 568, $536 \mathrm{~cm}^{-1}$. ${ }^{1} \mathrm{H} \mathrm{NMR}\left(\mathrm{CDCl}_{3}, 400 \mathrm{MHz}\right): \delta=8.03(\mathrm{dd}, J=8.3,0.8 \mathrm{~Hz}, 1 \mathrm{H}), 7.78(\mathrm{~d}, J=$ $8.2 \mathrm{~Hz}, 2 \mathrm{H}), 7.64(\mathrm{~s}, 1 \mathrm{H}), 7.53(\mathrm{dd}, J=7.8,0.7 \mathrm{~Hz}, 1 \mathrm{H}), 7.45(\mathrm{~d}, J=7.6$ $\mathrm{Hz}, 1 \mathrm{H}), 7.37-7.34(\mathrm{~m}, 1 \mathrm{H}), 7.28-7.26$ (m, $1 \mathrm{H}), 7.23$ (d, J = 8.6 Hz, 2 H), 7.14-7.11 (m, $1 \mathrm{H}), 6.83(\mathrm{t}, J=7.5 \mathrm{~Hz}, 1 \mathrm{H}), 6.65(\mathrm{~d}, J=8.0 \mathrm{~Hz}, 1 \mathrm{H})$, $5.35(\mathrm{~d}, J=5.6 \mathrm{~Hz}, 1 \mathrm{H}), 4.95-4.94(\mathrm{~m}, 1 \mathrm{H}), 3.91(\mathrm{br} \mathrm{s}, 1 \mathrm{H}), 3.60-3.57$ $(\mathrm{m}, 1 \mathrm{H}), 3.42(\mathrm{td}, J=11.4,2.6 \mathrm{~Hz}, 1 \mathrm{H}), 2.35(\mathrm{~s}, 3 \mathrm{H}), 2.33-2.27(\mathrm{~m}, 1$ H), 1.53-1.41 (m, $3 \mathrm{H}), 1.16-1.12(\mathrm{~m}, 1 \mathrm{H})$.

${ }^{13} \mathrm{C}$ NMR $\left(\mathrm{CDCl}_{3}, 100 \mathrm{MHz}\right): \delta=145.2,145.1,135.7,135.3,130.1$, 129.1, 128.4, 127.9, 127.0, 125.3, 123.6, 123.5, 123.0, 120.4, 119.8, $119.0,114.9,114.2,72.5,60.8,52.4,36.7,25.5,21.8,18.7$.

LC-MS (ESI): $m / z=457[\mathrm{M}-\mathrm{H}]^{-}$.

Anal. Calcd for $\mathrm{C}_{27} \mathrm{H}_{26} \mathrm{~N}_{2} \mathrm{O}_{3} \mathrm{~S}$ (458.576): C, 70.72; $\mathrm{H}, 5.72 ; \mathrm{N}, 6.11 ; \mathrm{S}$, 6.99. Found: C, 70.64; H, 5.38; N, 5.94; S, 7.12.

(士)-(4aS,5R,10bS)-5-(1-Tosyl-1H-indol-3-yl)-3,4,4a,5,6,10b-hexahydro-2H-pyrano[3,2-c]quinoline (5ag)

Prepared from aniline (1a), $N$-tosylindole-3-carboxaldehyde (2g), and 2,3-dihydropyran (3a) according to the general procedure; yield: 120 mg (28\%); white solid; $\mathrm{mp} 223-225^{\circ} \mathrm{C}$.

FT-IR (neat): 3375, 2935, 1605, 1368, 1176, 744, 572, $535 \mathrm{~cm}^{-1}$.

${ }^{1} \mathrm{H} \mathrm{NMR}\left(\mathrm{CDCl}_{3}, 400 \mathrm{MHz}\right): \delta=8.03(\mathrm{dd}, J=8.3,0.7 \mathrm{~Hz}, 1 \mathrm{H}), 7.77-7.73$ (m, $3 \mathrm{H}), 7.58(\mathrm{~s}, 1 \mathrm{H}), 7.36-7.32(\mathrm{~m}, 1 \mathrm{H}), 7.26-7.18(\mathrm{~m}, 4 \mathrm{H}), 7.12-$ $7.08(\mathrm{~m}, 1 \mathrm{H}), 6.73(\mathrm{td}, J=7.5,1.0 \mathrm{~Hz}, 1 \mathrm{H}), 6.52(\mathrm{~d}, J=8.0 \mathrm{~Hz}, 1 \mathrm{H}), 4.97$ (d, $J=10.9 \mathrm{~Hz}, 1 \mathrm{H}), 4.41$ (d, $J=2.8 \mathrm{~Hz}, 1 \mathrm{H}), 4.13-4.08(\mathrm{~m}, 2 \mathrm{H}), 3.72$ (td, $J=11.5,2.5 \mathrm{~Hz}, 1 \mathrm{H}), 2.38-2.33(\mathrm{~m}, 1 \mathrm{H}), 2.36(\mathrm{~s}, 3 \mathrm{H}), 1.86-1.76$ (m, $1 \mathrm{H}), 1.63(\mathrm{tt}, J=13.1,4.6 \mathrm{~Hz}, 1 \mathrm{H}), 1.42-1.27(\mathrm{~m}, 2 \mathrm{H})$.

${ }^{13} \mathrm{C}$ NMR $\left(\mathrm{CDCl}_{3}, 100 \mathrm{MHz}\right): \delta=145.3,144.7,136.0,135.2,131.1$, 130.1, 129.6, 129.4, 127.0, 125.2, 124.9, 123.4, 121.4, 121.0, 118.0, $114.5,114.2,74.6,68.7,48.1,37.0,24.5,22.1,21.8$.
LC-MS (ESI): $m / z=457[\mathrm{M}-\mathrm{H}]^{-}$.

Anal. Calcd for $\mathrm{C}_{27} \mathrm{H}_{26} \mathrm{~N}_{2} \mathrm{O}_{3} \mathrm{~S}$ (458.576): C, 70.72; H, 5.72; N, 6.11; S, 6.99. Found: C, 70.57; H, 5.44; N, 6.23; S, 6.89 .

\section{5-Methyl-2,3,3a,4,5,9b-hexahydrofuro[3,2-c]quinoline (10a)}

Prepared from $N$-methylaniline (1d), formaldehyde (2h), and 2,3-dihydrofuran (3b) according to the general procedure at r.t.; yield: 180 mg (96\%); pale yellow oil.

FT-IR (neat): 2937, 2863, 2818, 1607, 1497, 1294, $748 \mathrm{~cm}^{-1}$.

${ }^{1} \mathrm{H} \mathrm{NMR}\left(\mathrm{CDCl}_{3}, 400 \mathrm{MHz}\right): \delta=7.36(\mathrm{dd}, J=7.5,1.6 \mathrm{~Hz}, 1 \mathrm{H}), 7.25-7.18$ $(\mathrm{m}, 1 \mathrm{H}), 6.78(\mathrm{td}, J=7.4,1.0 \mathrm{~Hz}, 1 \mathrm{H}), 6.72(\mathrm{~d}, J=8.3 \mathrm{~Hz}, 1 \mathrm{H}), 4.60(\mathrm{~d}$, $J=5.5 \mathrm{~Hz}, 1 \mathrm{H}), 3.95(\mathrm{td}, J=8.4,5.9 \mathrm{~Hz}, 1 \mathrm{H}), 3.82(\mathrm{td}, J=8.8,6.3 \mathrm{~Hz}, 1$ H), $3.02(\mathrm{dd}, J=11.2,5.3 \mathrm{~Hz}, 1 \mathrm{H}), 2.90(\mathrm{~s}, 3 \mathrm{H}), 2.80(\mathrm{t}, J=11.1 \mathrm{~Hz}, 1$ H), 2.54 (dqd, $J=13.5,5.4,2.8 \mathrm{~Hz}, 1 \mathrm{H}), 2.34-2.18(\mathrm{~m}, 1 \mathrm{H}), 1.80-1.73$ $(\mathrm{m}, 1 \mathrm{H})$

${ }^{13} \mathrm{C}$ NMR $\left(\mathrm{CDCl}_{3}, 100 \mathrm{MHz}\right): \delta=147.1,131.1,129.0,121.7,117.4$, $111.8,75.8,65.1,52.5,39.3,35.9,30.0$.

GC-MS (EI, $70 \mathrm{eV}): m / z=189$ [M+1 $, 158,146,144$ (100\%).

Anal. Calcd for $\mathrm{C}_{12} \mathrm{H}_{15} \mathrm{NO}$ (189.258): C, 76.16; H, 7.99; N, 7.40. Found: C, 76.25; H, 8.17; N, 7.47

\section{1-(1-Methyl-1,2,3,4-tetrahydroquinolin-4-yl)pyrrolidin-2-one (10b)}

Prepared from $N$-methylaniline (1d), formaldehyde (2h), and $N$-vinylpiyrrolidone (3c) according to the general procedure at r.t.; yield: $176 \mathrm{mg}$ (78\%); white solid; mp $87-88^{\circ} \mathrm{C}$.

FT-IR (neat): 2950, 2872, 2819, 1671, 1500, 1418, 1287, $748 \mathrm{~cm}^{-1}$.

${ }^{1} \mathrm{H}$ NMR $\left(\mathrm{CDCl}_{3}, 400 \mathrm{MHz}\right): \delta=7.15-7.11(\mathrm{~m}, 1 \mathrm{H}), 6.88-6.86(\mathrm{~m}, 1 \mathrm{H})$, 6.67-6.62 (m, $2 \mathrm{H}), 5.41(\mathrm{dd}, J=9.3,6.0 \mathrm{~Hz}, 1 \mathrm{H}), 3.34$ (ddd, $J=11.7$, 9.7, 3.4 Hz, $1 \mathrm{H}), 3.26-3.18(\mathrm{~m}, 2 \mathrm{H}), 3.15-3.09(\mathrm{~m}, 1 \mathrm{H}), 2.88(\mathrm{~s}, 3 \mathrm{H})$, 2.50-2.46 (m, $2 \mathrm{H}), 2.19-2.10$ (m, $1 \mathrm{H}), 2.07-1.93(\mathrm{~m}, 3 \mathrm{H})$.

${ }^{13} \mathrm{C}$ NMR $\left(\mathrm{CDCl}_{3}, 100 \mathrm{MHz}\right): \delta=175.6,147.6,128.7,127.7,119.9$, $116.9,112.0,49.7,48.1,43.7,39.5,31.7,26.9,18.5$

GC-MS (EI, $70 \mathrm{eV}): m / z=230\left[\mathrm{M}^{+}\right], 201,159,144$ (100\%), 130.

Anal. Calcd for $\mathrm{C}_{14} \mathrm{H}_{18} \mathrm{~N}_{2} \mathrm{O}$ (230.311): C, 73.01; H, 7.88; N, 12.16 . Found: C, 73.25; H, 7.94; N, 12.08 .

\section{6-Benzyl-3,4,4a,5,6,10b-hexahydro-2H-pyrano[3,2-c]quinoline (10c)}

Prepared from $\mathrm{N}$-benzylaniline (1e), formaldehyde (2h), and 2,3-dihydropyran (3a) according to the general procedure at r.t.; yield: 163 mg (60\%); white solid; $\mathrm{mp} 126-127^{\circ} \mathrm{C}$.

FT-IR (neat): 2902, 2838, 1602, 1506, 1453, 1046, $743 \mathrm{~cm}^{-1}$.

${ }^{1} \mathrm{H} \mathrm{NMR}\left(\mathrm{CDCl}_{3}, 400 \mathrm{MHz}\right): \delta=7.34-7.23(\mathrm{~m}, 5 \mathrm{H}), 7.10-7.05(\mathrm{~m}, 1 \mathrm{H})$, $6.66(\mathrm{t}, J=7.3 \mathrm{~Hz}, 1 \mathrm{H}), 6.56(\mathrm{~d}, J=8.3 \mathrm{~Hz}, 1 \mathrm{H}), 4.52(\mathrm{~d}, J=16.9 \mathrm{~Hz}, 1$ H), 4.49 (br s, $1 \mathrm{H}), 4.47$ (d, J = 17.0 Hz, $1 \mathrm{H}), 4.03-3.99(\mathrm{~m}, 1 \mathrm{H}), 3.75-$ $3.68(\mathrm{~m}, 2 \mathrm{H}), 3.09$ (dd, $J=11.2,4.1 \mathrm{~Hz}, 1 \mathrm{H}), 2.26-2.19(\mathrm{~m}, 1 \mathrm{H}), 1.97-$ $1.88(\mathrm{~m}, 1 \mathrm{H}), 1.85-1.75$ (m, $2 \mathrm{H}), 1.50-1.43(\mathrm{~m}, 1 \mathrm{H})$.

${ }^{13} \mathrm{C}$ NMR $\left(\mathrm{CDCl}_{3}, 100 \mathrm{MHz}\right): \delta=145.7,138.9,131.1,129.7,128.8$, $127.1,126.8,121.3,116.5,111.6,74.5,67.6,55.4,49.7,32.4,25.6$, 22.7

GC-MS (EI, $70 \mathrm{eV}): m / z=279\left[\mathrm{M}^{+}\right], 220,188,144,130,91(100 \%)$.

Anal. Calcd for $\mathrm{C}_{19} \mathrm{H}_{21} \mathrm{NO}$ (279.383): C, 81.68; H, 7.58; N, 5.01. Found: C, 81.74; H, 7.62; N, 5.29. 
Ethyl ( \pm )-(3aS,4S,9bS)-5-Methyl-2,3,3a,4,5,9b-hexahydrofuro[3,2c]quinoline-4-carboxylate (syn-10d)

Prepared from $N$-methylaniline (1d), ethyl glyoxylate (2i), and 2,3-dihydrofuran (3b) according to the general procedure at r.t.; yield: 47 mg (19\%); colorless oil.

FT-IR (neat): 3389, 2878, 1721, 1497, 1185, 1026, $748 \mathrm{~cm}^{-1}$.

${ }^{1} \mathrm{H} \mathrm{NMR}\left(\mathrm{CDCl}_{3}, 400 \mathrm{MHz}\right): \delta=7.32(\mathrm{dd}, J=7.6,1.2 \mathrm{~Hz}, 1 \mathrm{H}), 7.26-7.20$ $(\mathrm{m}, 1 \mathrm{H}), 6.79(\mathrm{td}, J=7.4,1.1 \mathrm{~Hz}, 1 \mathrm{H}), 6.74(\mathrm{~d}, J=8.3 \mathrm{~Hz}, 1 \mathrm{H}), 4.60(\mathrm{~d}$, $J=5.1 \mathrm{~Hz}, 1 \mathrm{H}), 4.12-3.99(\mathrm{~m}, 2 \mathrm{H}), 3.88(\mathrm{~d}, J=6.0 \mathrm{~Hz}, 1 \mathrm{H}), 3.84-3.68$ (m, 2 H), 2.91 (s, $3 \mathrm{H}), 2.88-2.78(\mathrm{~m}, 1 \mathrm{H}), 2.48-2.40$ (m, $1 \mathrm{H}), 2.19-$ $2.10(\mathrm{~m}, 1 \mathrm{H}), 1.13(\mathrm{t}, J=7.1 \mathrm{~Hz}, 3 \mathrm{H})$.

${ }^{13} \mathrm{C}$ NMR $\left(\mathrm{CDCl}_{3}, 100 \mathrm{MHz}\right): \delta=171.4,145.9,130.5,129.4,121.3$, 118.0, 112.2, 75.1, 65.6, 63.2, 61.1, 39.7, 39.1, 27.6, 14.2.

GC-MS (EI, $70 \mathrm{eV}): m / z=261\left[\mathrm{M}^{+}\right], 188$ (100\%), 158, 144.

Anal. Calcd for $\mathrm{C}_{15} \mathrm{H}_{19} \mathrm{NO}_{3}$ (261.321): C, 68.94; $\mathrm{H}, 7.33$; N, 5.36. Found: C, $68.87 ; \mathrm{H}, 7.39 ; \mathrm{N}, 5.48$.

\section{Ethyl ( \pm )-(3aS,4R,9bS)-5-Methyl-2,3,3a,4,5,9b-hexahydrofuro[3,2- c]quinoline-4-carboxylate (anti-10d)}

Prepared from $N$-methylaniline (1d), ethyl glyoxylate (2i), and 2,3-dihydrofuran (3b) according to the general procedure at r.t. The product anti-10d was obtained as an enriched diastereomeric mixture.

${ }^{1} \mathrm{H} \mathrm{NMR}\left(\mathrm{CDCl}_{3}, 400 \mathrm{MHz}\right): \delta=7.29-7.26(\mathrm{~m}, 1 \mathrm{H}), 7.18$ (td, $J=8.2,1.7$ $\mathrm{Hz}, 1 \mathrm{H}), 6.80-6.75(\mathrm{~m}, 1 \mathrm{H}), 6.66(\mathrm{~d}, J=8.3 \mathrm{~Hz}, 1 \mathrm{H}), 4.94(\mathrm{~d}, J=7.6 \mathrm{~Hz}$, $1 \mathrm{H}$ ), 4.14 (qdd, $J=7.1,2.1,0.8 \mathrm{~Hz}, 2 \mathrm{H}$ ), 3.92-3.70 (m, $3 \mathrm{H}$ ), 3.00 (ddd, $J=16.9,8.1,4.1 \mathrm{~Hz}, 1 \mathrm{H}), 2.95(\mathrm{~s}, 3 \mathrm{H}), 2.23-2.15(\mathrm{~m}, 1 \mathrm{H}), 2.06(\mathrm{dq}, J=$ $12.1,8.2 \mathrm{~Hz}, 1 \mathrm{H}$ ), 1.19 (td, $J=7.1,0.8 \mathrm{~Hz}, 3 \mathrm{H}$ ).

GC-MS (EI, $70 \mathrm{eV}): m / z=261\left[\mathrm{M}^{+}\right], 188$ (100\%), 158, 144.

\section{syn-11 and anti-11}

Aniline (1a; $1 \mathrm{mmol}$ ), formaldehyde (2h; $2.2 \mathrm{mmol})$, 2,3-dihydrofuran (3b; $2.4 \mathrm{mmol}), \mathrm{CeCl}_{3} \cdot 7 \mathrm{H}_{2} \mathrm{O}(0.3 \mathrm{mmol}), \mathrm{NaI}(0.3 \mathrm{mmol})$, and $\mathrm{MgSO}_{4}(200 \mathrm{mg})$ were stirred together in $\mathrm{MeCN}(5 \mathrm{~mL})$ at $50{ }^{\circ} \mathrm{C}$ for $2 \mathrm{~h}$. After consumption of the starting aniline, the reaction was stopped and the workup was done according to the general procedure. The anti/syn configuration of compounds $\mathbf{1 1}$ were assigned according to those reported ${ }^{28}$ for 2-methyl-3b,6,7,7a,10a,12,13,14a-octahydro$5 H, 8 H, 10 H, 11 H$-pyrano[3,2-c]pyrano[2',3':4,5]pyrido[3,2,1-ij]quinoline.

\section{(3bR,6aR,9aS,12aS)-3b,5,6,6a,7,9,9a,10,11,12a-Decahydrofuro[3,2-} c]furo[2',3':4,5]pyrido[3,2,1-ij]quinoline (syn-11)

Prepared from $\mathbf{1 a}, \mathbf{2 h}$, and $\mathbf{3 b}$ according to the above procedure; yield: $93 \mathrm{mg}$ (37\%); white solid; $\mathrm{mp} 87-88^{\circ} \mathrm{C}$.

FT-IR (neat): 2949, 2863, 1601, 1491, 1445, 1043, 1018, $751 \mathrm{~cm}^{-1}$.

${ }^{1} \mathrm{H} \mathrm{NMR}\left(\mathrm{CDCl}_{3}, 400 \mathrm{MHz}\right): \delta=7.26(\mathrm{~d}, J=7.5 \mathrm{~Hz}, 2 \mathrm{H}), 6.79(\mathrm{t}, J=7.5$ $\mathrm{Hz}, 1 \mathrm{H}$ ), 4.75 (d, $J=6.5 \mathrm{~Hz}, 2 \mathrm{H}), 3.88(\mathrm{td}, J=8.4,5.2 \mathrm{~Hz}, 2 \mathrm{H}), 3.79$ (td, $J=8.3,7.1 \mathrm{~Hz}, 2 \mathrm{H}), 2.98(\mathrm{dd}, J=11.3,4.4 \mathrm{~Hz}, 2 \mathrm{H}), 2.82(\mathrm{dd}, J=11.4$, $7.7 \mathrm{~Hz}, 2 \mathrm{H}$ ), 2.64-2.56 (m, $2 \mathrm{H}), 2.20-2.12$ (m, $2 \mathrm{H}$ ), 1.96-1.87 (m, 2 $\mathrm{H})$.

${ }^{13} \mathrm{C} \mathrm{NMR}\left(\mathrm{CDCl}_{3}, 100 \mathrm{MHz}\right): \delta=144.1,130.9,122.5,118.5,75.8,66.0$, 51.7, 36.5, 29.8.

GC-MS (EI, $70 \mathrm{eV}): m / z=257\left[\mathrm{M}^{+}\right], 226,214,212(100 \%), 182,168$, 167, 144, 55.

Anal. Calcd for $\mathrm{C}_{16} \mathrm{H}_{19} \mathrm{NO}_{2}$ (257.333): C, 74.68; $\mathrm{H}, 7.44 ; \mathrm{N}, 5.44$. Found: C, 74.64; H, 7.53; N, 5.38.
(3bS,6aS,9aS,12aS)-3b,5,6,6a,7,9,9a,10,11,12a-Decahydrofuro[3,2c]furo[2',3':4,5]pyrido[3,2,1-ij]quinoline (anti-11)

Prepared from $\mathbf{1 a}, \mathbf{2 h}$, and $\mathbf{3 b}$ according to the above procedure; yield: $74 \mathrm{mg}$ (29\%); white solid; mp $112-113^{\circ} \mathrm{C}$.

FT-IR (neat): 2929, 2833, 1601, 1486, 1290, 1053, 1033, 787, $767 \mathrm{~cm}^{-1}$. ${ }^{1} \mathrm{H} \mathrm{NMR}\left(\mathrm{CDCl}_{3}, 400 \mathrm{MHz}\right): \delta=7.32(\mathrm{~d}, J=7.5 \mathrm{~Hz}, 2 \mathrm{H}), 6.80(\mathrm{t}, J=7.5$ $\mathrm{Hz}, 1 \mathrm{H}), 4.53(\mathrm{~d}, J=4.9 \mathrm{~Hz}, 2 \mathrm{H}), 3.96(\mathrm{td}, J=8.4,6.1 \mathrm{~Hz}, 2 \mathrm{H}), 3.82(\mathrm{td}$, $J=8.9,6.0 \mathrm{~Hz}, 2 \mathrm{H}$ ), 2.94 (dd, $J=10.5,4.8 \mathrm{~Hz}, 2 \mathrm{H}), 2.63-2.58(\mathrm{~m}, 2 \mathrm{H})$, 2.55-2.48 (m, $2 \mathrm{H}), 2.32-2.23$ (m, $2 \mathrm{H}), 1.76-1.69$ (m, $2 \mathrm{H})$.

${ }^{13} \mathrm{C}$ NMR $\left(\mathrm{CDCl}_{3}, 100 \mathrm{MHz}\right): \delta=144.3,131.4,121.8,118.3,76.1,65.3$, $51.5,35.6,30.4$.

GC-MS (EI, $70 \mathrm{eV}): m / z=257\left[\mathrm{M}^{+}\right], 226,214,212$ (100\%), 182, 168, 167, 144, 55.

Anal. Calcd for $\mathrm{C}_{16} \mathrm{H}_{19} \mathrm{NO}_{2}$ (257.333): C, 74.68; $\mathrm{H}, 7.44 ; \mathrm{N}, 5.44$. Found: C, 74.68; H, 7.47; N, 5.41 .

\section{Funding Information}

This work was supported by grants from University of Camerino (Fondo di Ateneo per la Ricerca 2014-2015).

\section{Supporting Information}

Supporting information for this article is available online at https://doi.org/10.1055/s-0036-1589104.

\section{References}

(1) Povarov, L. S. Russ. Chem. Rev. 1967, 36, 656.

(2) Selected reviews on the Povarov reaction: (a) Glushkov, V. A.; Tolstikov, A. G. Russ. Chem. Rev. 2008, 77, 137. (b) Kouznetsov, V. V. Tetrahedron 2009, 65, 2721. (c) Sridharan, V.; Suryavanshi, P. A.; Menendez, J. C. Chem. Rev. 2011, 111, 7157. (d) Masson, G.; Lalli, C.; Benohoud, M.; Dagousset, G. Chem. Soc. Rev. 2013, 42, 902. (e) Jiang, X. X.; Wang, R. Chem. Rev. 2013, 113, 5515.

(3) Schiemann, K.; Finsinger, D.; Zenke, F.; Amendt, C.; Knoechel, T.; Bruge, D.; Buchstaller, H.-P.; Emde, U.; Staehle, W.; Anzali, S. Bioorg. Med. Chem. Lett. 2010, 20, 1491; and references cited therein.

(4) (a) Venkat Narsaiah, A.; Ramesh Reddy, A.; Subba Reddy, B. V.; Yadav, J. S. Synth. Commun. 2010, 40, 1750. (b) Yu, Y.; Zhou, J.; Yao, Z.; Xu, F.; Shen, Q. Heteroat. Chem. 2010, 21, 351. (c) Zhou, Z.; Xu, F.; Han, X.; Zhou, J.; Shen, Q. Eur.J. Org. Chem. 2007, 5265.

(5) Palaniappan, S.; Rajender, B.; Umashankar, M. J. Mol. Catal. A: Chem. 2012, 352, 70; and references cited therein.

(6) (a) Olmos, A.; Sommer, J.; Pale, P. Chem. Eur. J. 2011, 17, 1907. (b) Kamble, V. T.; Davane, B. S.; Chavan, S. A.; Muley, D. B.; Atkore, S. T. Chin. Chem. Lett. 2010, 21, 265. (c) Kumar, A.; Srivastava, S.; Gupta, G.; Chaturvedi, V.; Sinha, S.; Srivastava, R. ACS Comb. Sci. 2011, 13, 65.

(7) Li, L.-P.; Cai, X.; Xiang, Y.; Zhang, Y.; Song, J.; Yang, D.-C.; Guan, Z.; He, Y.-H. Green Chem. 2015, 17, 3148.

(8) (a) Kobayashi, S. Lanthanide: Chemistry and Use in Organic Synthesis; Springer-Verlag: Heidelberg, 1999. (b) Kobayashi, S. Synlett 1994, 689.

(9) For recent reviews on this argument, see: (a) Dalpozzo, R.; De Nino, A.; Bartoli, G.; Sambri, L.; Marcantoni, E. Recent Res. Dev. Org. Chem. 2001, 5, 181. (b) Bartoli, G.; Marcantoni, E.; Sambri, 
L. Seminars in Organic Synthesis, XXV Summer School 'A. Corbella', Gargnano (BS); Italian Chemical Society: Rome, 2000, 117-138. (c) Liu, H. J.; Shia, K. S.; Shang, X.; Zhu, B. Y. Tetrahedron 1999, 55, 3803.

(10) Bartoli, G.; Marcantoni, E.; Marcolini, M.; Sambri, L. Chem. Rev. 2010, $110,6104$.

(11) Properzi, R.; Marcantoni, E. Chem. Soc. Rev. 2014, 43, 779.

(12) (a) Dhara, D.; Gayen, K. S.; Khamarni, S.; Pandit, P.; Ghosh, S.; Maiti, D. K. J. Org. Chem. 2012, 77, 10441. (b) Kidwai, M.; Jahan, A. J. Braz. Chem. Soc. 2010, 21, 2175.

(13) Cioc, R. C.; Ruijter, E.; Orru, R. V. A. Green Chem. 2014, 16, 2958.

(14) Bartoli, G.; Marcantoni, E.; Sambri, L. Synlett 2003, 2101; and references cited therein.

(15) For some selected examples, see: (a) Li, W. Z.; Peng, Y. Org. Lett. 2005, 7, 3069. (b) Bartoli, G.; Giuliani, A.; Marcantoni, E.; Massaccesi, M.; Melchiorre, P.; Lanari, S.; Sambri, L. Adv. Synth. Catal. 2005, 347, 1673. (c) Yeh, M. P.; Yeh, W.; Tu, L.; Wu, J. Tetrahedron 2006, 62, 7466. (d) Bartoli, G.; Beleggia, R.; Giuli, S.; Giuliani, A.; Marcantoni, E.; Massaccesi, M.; Paoletti, M. Tetrahedron Lett. 2006, 47, 6501. (e) Kantevari, S.; Addla, D.; Sridhar, B. Synthesis 2010, 3745. (f) Lee, I. Y.; Lee, K. C.; Lee, H. W. Bull. Korean Chem. Soc. 2012, 33, 3535. (g) Nookaraju, U.; Begari, E.; Yetra, R. R.; Kumar, P. ChemistrySelect 2016, 1, 81. (h) Bartoli, G.; Bosco, M.; Carlone, A.; Locatelli, L.; Marcantoni, E.; Melchiorre, P.; Sambri, L. Adv. Synth. Catal. 2006, 348, 905. (i) Bartoli, G.; Bosco, M.; Bellucci, M. C.; Marcantoni, E.; Sambri, L.; Torregiani, E. Eur. J. Org. Chem. 1999, 617.

(16) Kobayashi, S.; Ishitani, H.; Nagayama, S. Synthesis 1995, 1195.

(17) (a) Sridharan, V.; Suryavanshi, P. A.; Menéndez, J. C. Chem. Rev. 2011, 111, 7157. (b) Powell, D. A.; Batey, R. A. Org. Lett. 2002, 4, 2913.

(18) Camps, P.; Formosa, X.; Galdeano, C.; Muñoz-Torrero, D.; Ramírez, L.; Gómez, E.; Isambert, N.; Lavilla, R.; Badia, A.; Clos, M. V.; Bartolini, M.; Mancini, F.; Andrisano, V.; Arce, M. P.; Rodríguez-Franco, M. I.; Huertas, Ó.; Dafni, T.; Luque, F. J. J. Med. Chem. 2009, 52, 5365.
(19) Yamada, N.; Kadowaki, S.; Takahashi, K.; Umezu, K. Biochem. Pharmacol. 1992, 44, 1211.

(20) Mukherjee, S.; Pal, M. Curr. Med. Chem. 2013, 20, 4386.

(21) Majumdar, K. C.; Ponra, S.; Ghosh, T.; Sadhukhan, R.; Ghosh, U. Eur. J. Med. Chem. 2014, 71, 306.

(22) (a) Behbahani, F. K.; Ziaei, P. J. Korean Chem. Soc. 2014, 58, 44. (b) Yadav, J. S.; Reddy, B. V. S.; Srinivasa Rao, R.; Kiran Kumar, S.; Kunwar, A. C. Tetrahedron 2002, 58, 7891. (c) Cheng, X.; Hii, K. K. Tetrahedron 2001, 57, 5445.

(23) Cimarelli, C.; Di Nicola, M.; Diomedi, S.; Giovannini, R.; Hamprect, D.; Properzi, R.; Sorana, F.; Marcantoni, E. Org. Biomol. Chem. 2015, 13, 11687.

(24) Bartoli, G.; Bartolacci, M.; Bosco, M.; Foglia, G.; Giuliani, V.; Marcantoni, E.; Sambri, L.; Torregiani, E. J. Org. Chem. 2003, 68, 4594.

(25) Bartoli, G.; Di Antonio, G.; Giuli, S.; Marcantoni, E.; Marcolini, M.; Paoletti, M. Synthesis 2008, 320.

(26) Bartoli, G.; Fernàndez-Bolaños, J. G.; Di Antonio, G.; Foglia, G.; Giuli, S.; Gunnella, R.; Mancinelli, M.; Marcantoni, E.; Paoletti, M. J. Org. Chem. 2007, 72, 6029; and references cited therein.

(27) Katritzky, A. R.; Rachwal, S.; Rachwal, B. Tetrahedron 1996, 52, 15031.

(28) Legros, J.; Crousse, B.; Ourevitch, M.; Bonnet-Delpon, D. Synlett 2006, 1899.

(29) (a) Yadav, S.; Reddy, B. V. S.; Gayathri, K. U.; Prasad, A. R. Synthesis 2002, 2537. (b) Zhang, J.; Li, C. J. Org. Chem. 2002, 67, 3969.

(30) Bartoli, G.; Giovannini, R.; Giuliani, A.; Marcantoni, E.; Massaccesi, M.; Melchiorre, P.; Paoletti, M.; Sambri, L. Eur.J. Org. Chem. 2006, 1476.

(31) (a) Shindoh, N.; Tokuyama, H.; Takemoto, Y.; Takasu, K. J. Org. Chem. 2008, 73, 7451. (b) Pericherla, K.; Kumar, A.; Jha, A. Org. Lett. 2013, 15, 4078.

(32) Mellor, J. M.; Merriman, G. D. Tetrahedron 1995, 51, 6115. 